\title{
Proses berpikir siswa kelas X dalam menyelesaikan masalah nilai mutlak berdasarkan teori SWARTZ
}

\author{
Kun Solihatul Ummah, Edy Bambang Irawan* \\ Universitas Negeri Malang, Jl. Semarang No. 5 Malang, Jawa Timur, Indonesia \\ *Penulis korespondensi, Surel: edy.bambang.fmipa@um.ac.id
}

Paper received: 01-11-2021; revised: 15-11-2021; accepted: 30-11-2021

\begin{abstract}
Abstrak
Hasil studi pendahuluan menunjukkan bahwa siswa banyak melakukan kesalahan dalam memecahkan masalah nilai mutlak. Hal ini dapat dilihat di SMA Negeri 7 Malang, bahwa kurang dari 30 persen siswa mendapat nilai di atas 70 . Penelitian ini bertujuan untuk mendeskripsikan proses berpikir siswa dalam memecahkan masalah nilai mutlak berdasarkan Teori Swartz. Pendekatan yang digunakan adalah penelitian kualitatif. Hasil penelitian menunjukkan bahwa proses berpikir siswa dimulai dengan tahap menghasilkan ide,yakni siswa membentuk persamaan dan pertidaksamaan nilai mutlak.Selanjutnya siswa menjelaskan ide yang telah dibuat dengan menyusun ide yang telah dibentuk menjadi langkah-langkah penyelesaian masalah yang urut serta menjelaskan masing-masing tahapan penyelesaian masalah yang telah dibentuk. Selanjutnya, siswa menilai kelayakan ide-ide dengan menguraikan hal-hal yang mendasarinya dalam membentuk ide penyelesaian masalah. Pada tahap berpikir kompleks, siswa menuliskan kesimpulan dengan menentukan himpunan penyelesaian dari masalah nilai mutlak.
\end{abstract}

Kata kunci: proses berpikir; penyelesaian masalah; nilai mutlak; Teori Swartz

\section{Pendahuluan}

Matematika sebagai salah satu mata pelajaran yang diberikan di sekolah memegang peranan penting bukan hanya dalam bidang pendidikan, bahkan dalam kehidupan sehari-hari kebutuhan memahami matematika akan terus meningkat. Pada era modern ini, orang yang mampu memahami matematika akan lebih mudah dalam menghadapi tantangan di masa depan (NCTM, 2000). Sebagai salah satu mata pelajaran wajib yang disampaikan di sekolah, matematika diajarkan di tingkat pendidikan dasar dan pendidikan menengah. Sesuai dengan kurikulum di Indonesia, kemampuan pemecahan masalah merupakan fokus yang harus dicapai ketika mempelajari matematika. Menurut Akinmola (2014) melalui pembelajaran dan penerapan matematika, siswa dapat mengembangkan kemampuan berhitung, bernalar, keterampilan berpikir dan yang terpenting adalah kemampuan memecahkan masalah. Begitu pentingnya matematika dipelajari dan begitu pentingnya kemampuan pemecahan masalah dikuasai. Berdasarkan uji pendahuluan peneliti yang dilakukan di SMAN 7 Malang, yakni pada kelas X MIPA 4, X MIPA 5 dan X MIPA 6, lebih dari 70\% siswa memperoleh nilai dibawah 70. Berikut salah satu jawaban siswa saat mengerjakan soal tes yang diberikan.

\section{Gambar 1 Jawaban Siswa Saat Mengerjakan Soal yang Diberikan}

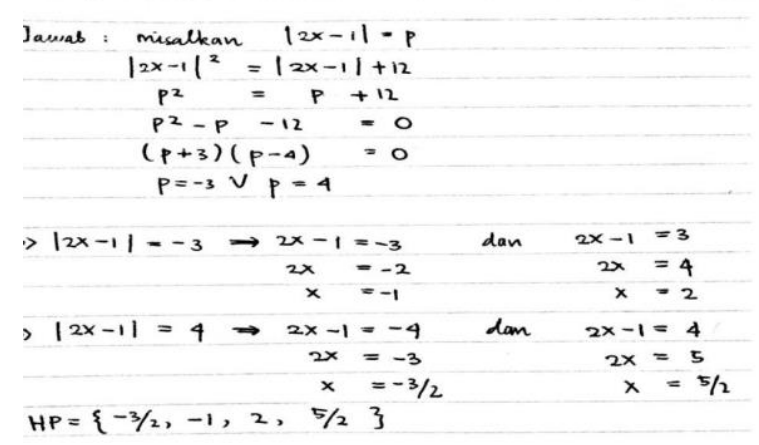

This work is licensed under a Creative Commons Attribution-ShareAlike 4.0 International License. 
Berdasarkan Gambar 1 siswa mengalami kesalahan saat menarik kesimpulan. Hal tersebut dikarenakan dalam menarik kesimpulan, siswa kurang mampu berpikir secara kompleks dan siswa belum mampu menilai kelayakan ide yang telah dibuat yakni mempertimbangkan mana yang termasuk selesaian dan bukan selesaian serta menelaah apakah jawaban yang ada mampu menjawab masalah atau tidak. Dengan demikian jawaban tersebut menunjukkan bahwa kesalahan terjadi pada salah satu tahapan proses berpikir siswa.

Sesuai dengan Gambar 1 dalam menyelesaikan masalah, siswa dituntut untuk menemukan solusi dari masalah yang ada. Siswa akan melakukan tahapan-tahapan berpikir atau dapat dikatakan bahwa siswa akan melakukan suatu proses berpikir yang bertujuan untuk menemukan solusi dalam menyelesaikan masalah (Jessica, 2016). Pendeskripsian proses berpikir siswa dalam menyelesaikan masalah nilai mutlak berguna untuk mengetahui jalan pikir siswa, dasar-dasar berpikir siswa, kesulitan yang dihadapi siswa, dan kelemahan atau pengetahuan yang dimiliki oleh siswa tersebut. Hal tersebut sesuai dengan (Supriadi,dkk, 2015) yang mengungkapkan bahwa tugas pokok seorang pendidik matematika adalah menelaah proses berpikir siswa guna memperbaiki pengajaran matematika di sekolah.

Berkaitan dengan nilai mutlak, beberapa penelitian terdahulu, salah satunya oleh Jessica (2016) menemukan bahwa siswa bahkan mahasiswa mengalami kesulitan dalam menemukan solusi yang tepat, mereka menyelesaikan soal seolah-olah tidak ada nilai mutlak dalam persamaan dan pertidaksamaan yang diberikan, dan mereka tidak dapat sepenuhnya mengaplikasikan konsep nilai mutlak dalam penyelesaiannya. Selain itu, observasi awal yang dilakukan oleh peneliti menunjukkan bahwa proses berpikir siswa dalam menyelesaikan masalah nilai mutlak masih kurang maksimal, meskipun subjek penelitian dalam observasi awal ini telah menempuh mata pelajaran yang berkaitan dengan nilai mutlak.

Proses berpikir siswa dalam menyelesaikan masalah nilai mutlak dalam penelitian ini dikaji menggunakan tahap-tahap proses berpikir milik Swartz. Menurut Swartz, dkk (1998) mendeskripsikan bahwa seberapa baik seseorang berpikir dapat dilihat dari kemahiran atau kepandaian dalam menyelesaikan masalah. Swartz, dkk (1998) juga menyebutkan tahaptahap proses berpikir yakni menghasilkan ide-ide (generating ideas), menjelaskan ide-ide (clarifying ideas), menilai kelayakan/kepantasan ide-ide (assessing the reasonableness of ideas) dan berpikir kompleks (complex thinking).

Berdasarkan uraian yang telah disebutkan di atas dan temuan peneliti di lapangan saat melakukan penelitian awal, maka perlu dilakukan penelitian lanjutan untuk mengetahui bagaimana proses berpikir siswa dalam menyelesaikan masalah matematika khususnya pada materi nilai mutlak.

\section{Metode}

Penelitian ini menggunakan pendekatan kualitatif jenis deskriptif. Penelitian dilakukan di SMAN 7 Malang. Subjek penelitian ini akan dipilih dari tiga puluh dua siswa kelas XI MIPA 
5 yang telah diajarkan materi nilai mutlak sebelumnya. Dari dari tiga puluh dua siswa kelas XI MIPA 5, akan dipilih tiga orang siswa sebagai subjek penelitian dengan mengamati proses berpikir siswa dalam menyelesaikan masalah nilai mutlak.

Instrumen penelitian yang digunakan dalam penelitian ini adalah lembar tes yang terdapat dua soal yakni soal tentang persamaan nilai mutlak seta pertidaksamaan nilai mutlak dan wawancara. Instrumen penelitian berupa lembar tes merupakan soal yang digunakan untuk menentukan subjek penelitian. Instrumen penelitian yang berupa wawancara digunakan untuk menggali proses berpikir siswa dalam menyelesaikan masalah nilai mutlak.

\section{Hasil dan Pembahasan}

Penelitian dilakukan dengan memberikan tes matematika dengan pokok bahasan persamaan dan pertidaksamaan nilai mutlak kepada siswa kelas X MIPA 5 yang berjumlah 32 siswa di SMA Negeri 7 Malang. Berdasarkan hasil tes dan pertimbangan kemampuan komunikasi siswa yang diperoleh melalui wawancara dengan guru kelas, peneliti mempertimbangkan 3 orang siswa untuk dipilih sebagai subjek. Ketiga siswa tersebut diminta untuk menjelaskan secara lisan mengenai jawaban yang telah ditulis, selain itu peneliti juga mengajukan beberapa pertanyaan dasar berkaitan dengan proses pengerjaan siswa dalam memperoleh jawaban. Setelah melakukan wawancara dengan ketigaa siswa tersebut, peneliti menelaah hasil wawancara dan memutuskan untuk menjadikan 3 siswa tersebut sebagai subjek penelitian utama dengan alasan ketiga siswa tersebut dinilai mampu menjelaskan proses berpikirnya dengan baik dibanding siswa lainnya. Berikut akan dijelaskan bagaimana proses berpikir siswa dalam menyelesaikan masalah nilai mutlak berdasarkan Teori Swartz.

\section{Menghasilkan ide-ide (generating ideas)}

Pada penelitian ini, dapat diketahui bahwa subjek penelitian menghasilkan ide dengan membaca soal dan menghubungkannya dengan pengetahuan sebelumnya. Hal ini sesuai dengan Teori Swartz,dkk.(1998) yang menjelaskan bahwa salah satu syarat menghasilkan ide adalah menggunakan pengetahuan masa lalu. Pada tahap menghasilkan ide dapat dilihat bahwa untuk menyelesaikan masalah, S1 mengerjakan soal nomor 1 dimulai dengan membentuk ide berupa persamaan | | | | dan mengerjakan soal nomor 2 dengan membentuk ide awal berupa pertidaksamaan | | . .S2 adalah subjek yang mengerjakan benar untuk soal nomor 2, untuk mengerjakan soal tersebut S2 membentuk ide dengan membentuk pertidaksamaan | | . Sedangkan S3 mengerjakan benar untuk soal nomor 1 dan membentuk ide awal berupa persamaan || ||. Baik S1, S2 dan S3 mampu menghasilkan ide dengan cara memahami masalah yang terdapat pada soal. Dengan memahami masalah, berarti mereka mengetahui apa yang akan dicari dan mengetahui informasi-informasi apa yang dapat digunakan untuk menyelesaikan masalah yang ada. Setelah memahami masalah, S1, S2 dan S3 mengolah informasi yang ada dan mengaitkannya dengan pengetahuan yang telah dimiliki agar dapat membentuk ide penyelesaian masalah. 


\section{Menjelaskan ide-ide (clarifying ideas)}

Hasil penelitian ini menunjukkan bahwa siswa mampu menjelaskan ide yang dihasilkan sesuai dengan Teori Swartz. Menurut Swartz,dkk. (1998), salah satu cara siswa mengklarifikasi ide adalah dengan menjelaskan informasi mengenai bagian yang diketahui dan ditanyakan, selanjutnya siswa tersebut menghubungkan dengan materi yang berkaitan dengan masalah tersebut. Selain itu, kedua subjek penelitian menjelaskan urutan idenya dalam menyelesaikan masalah sesuai dengan Teori Swartz (1998) yaitu membuat urutan ideide tersebut (sequencing). Kedua subjek penelitian juga menjelaskan setiap langkah yang mereka tulis dalam lembar jawaban mereka pada saat wawancara.

Cara mengklarifikasi pemahaman adalah melalui komunikasi (NCTM,2000). Komunikasi yang dilakukan pada penelitian ini adalah ketika peneliti melakukan wawancara terhadap subjek penelitian.

Dalam penelitian ini, cara pengklarifikasian ide yang dilakukan oleh ketigasubjek penelitian sesuai teori Swartz yaitu menganalisis ide-ide (analyzing ideas) dan menganalisis argumen (analyzing arguments). Menganalisis merupakan memecahkan suatu permasalahan dengan memisahkan tiap-tiap bagian dari permasalahan dan mencari kriteria dari tiap-tiap bagian tersebut dan mencari tahu bagaimana keterkaitan tersebut dapat menimbulkan permasalahan.

Saat mengerjakan soal nomor 1, S1 dan S3 menjelaskan ide dengan mengembangkan idenya yang telah dibentuk menjadi suatu langkah-langkah penyelesaian masalah yang urut. S1 dan S3 menjabarkan masing-masing bentuk | $\quad \mid$ dan $|\quad|$ sesuai definisi nilai mutlak. Setelah menjabarkan kedua bentuk tersebut, S1 dan S3 menyelesaikan persamaan awal dengan membaginya menjadi empat kasus hingga memperoleh suatu nilai . Sementara, untuk mengerjakan soal nomor 2, S1 dan S2 menjelaskan ide dengan mendefinisikan bentuk

| | menjadi dan . Dan menyelesaikan pertidaksamaan

| | dengan membaginya menjadi dua kasus yakni dan

, sehingga dengan menghitung dua kasus tersebut akan diperoleh suatu nilai .S1, S2 dan S3 juga menjelaskan setiap langkah-langkah yang mereka tulis saat menyelesaikan masalah pada sesi wawancara.

\section{Menilai kelayakan ide-ide (assessing the reasonableness of ideas)}

Dalam penelitian ini, kedua subjek penelitian menggunakan pengetahuan dasar untuk menghasilkan ide. Mereka menilai ide berdasarkan sumber yang diperoleh dari pengetahuan sebelumnya. Ketiga subjek penelitian mengungkapkan bahwa pengetahuan yang digunakan untuk mendasari idenya adalah pengetahuan tentang nilai mutlak. S1, S2 dan S3 mengatakan bahwa pelajaran tentang nilai mutlak sudah pernah didapatkan di semester 1 .

Dalam membentuk ide S1, S2 dan S3 melakukan asesmen keakuratan berdasarkan pada sumber-sumber yang dapat dipercaya (realiability of sources). Dalam kasus ini mereka 
menyebutkan bahwa ide yang digunakan untuk menyelesaikan masalah adalah konsep tentang nilai mutlak. Mereka mengungkapkan bahwa materi tentang nilai mutlak sudah dipelajari di semester1 dengan bantuan penjelasan guru dan mengerjakan beberapa soal yang berkaitan dengan materi.Artinya ide yang dibentuk S1, S2 dan S3 didasarkan pada sumber-sumber yang dapat dipercaya. Dengan menggunakan sumber yang dapat dipercaya, menyebabkan ide yang dibentuk menjadi benar.

Menilai kelayakan dan kualitas ide disebut mengevaluasi (Krik \& Ward,1999). Dalam mengevaluasi, terdapat dua aktivitas yaitu (1) penetapan kriteria: menetapkan standar untuk membuat penilaian, dan (2) verifikasi: mengkonfirmasikan akuransi klaim. Evaluasi meliputi mengecek (checking) dan mengkritisi (critiquing). Jika dikaitan dengan proses berpikir merencanakan dan mengimplementasikan maka mengecek akan mengarah pada penetapan sejauh mana suatu rencana berjalan dengan baik. Mengkritisi mengarah pada penilaian suatu produk atau operasi berdasarkan kriteria dan standar eksternal.

\section{Berpikir kompleks (complex thinking)}

Setelah melalui tahap menghasilkan ide, menjelaskan ide dan menilai kelayakan ide, subjek penelitian melakukan pengambilan keputusan bahwa ide yang digunakan mampu menjawab masalah. Selain itu, ketiga subjek juga melakukan penyelesaian masalah akhir dari soal yang diberikan dan menyusun kesimpulan berupa jawaban untuk setiapsoal. Hal ini sesuai dengan Teori Swartz bahwa pada tahap ini siswa menyelesaikan masalah (problem solving) dan membuat keputusan (decision making).

Dalam mengerjakan soal nomor 1, S1 dan S3 menarik kesimpulan berupa

\{ \}. Sedangkan untuk mengerjakan soal nomor 2, S1 dan S2 menarik kesimpulan berupa $\{\mid\}$.Secara keseluruhan, dapat diketahui

bahwa proses berpikir siswa dimulai dari membaca soal, mengetahui bagian yang diketahui dan ditanyakan dari soal, mencari kaitan antara bagian yang diketahui dan ditanyakan pada soal,. Setelah itu siswa mengaitkan informasi yang diperoleh di soal dengan pengetahuan sebelumnya untuk menyusun rencana penyelesaian,menyusun langkah-langkah penyelesaian dan yang terakhir membuat keputusan berupa kesimpulan yang mampu menjawab masalah. Berikut rangkuman proses berpikir yang dilakukan S1, S2 dan S3 dalam menyelesaikan masalah. 
Gambar 2 Diagram Proses Berpikir S1 dalam Menyelesaikan Soal Nomor 1

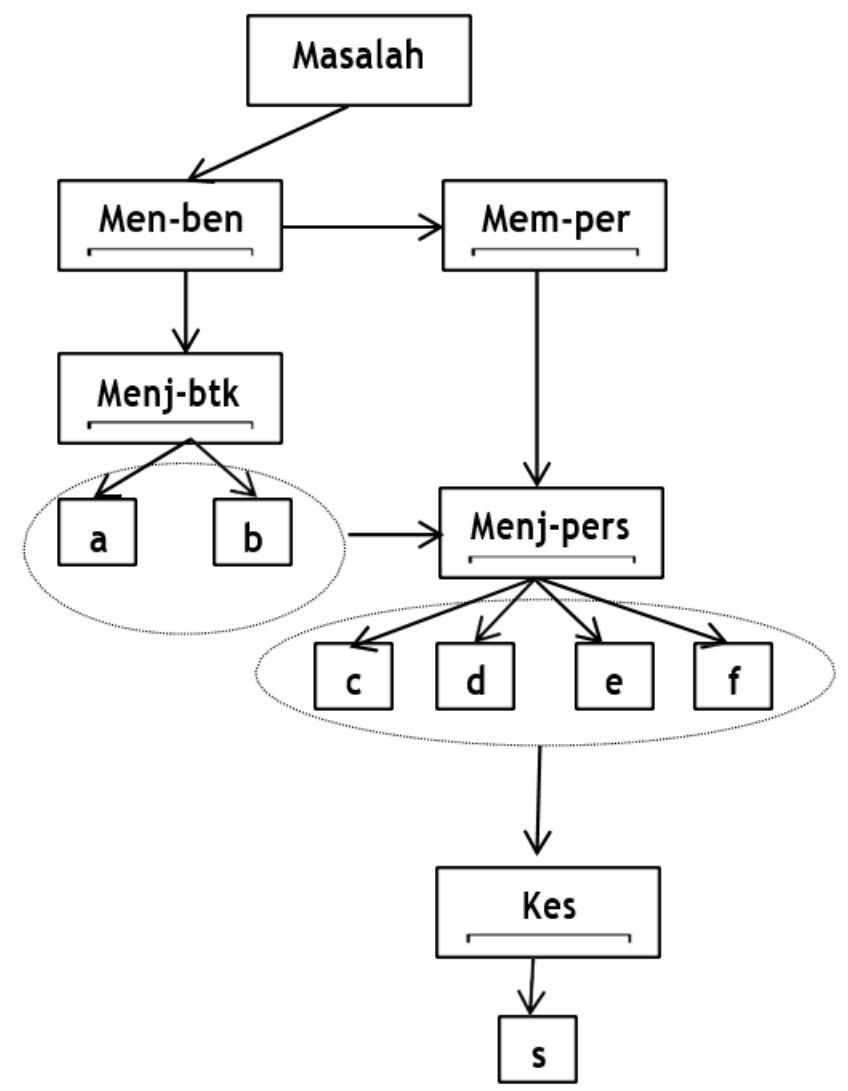

Tabel 1 Keterangan Diagram Proses berpikir S1

\begin{tabular}{|l|l|}
\hline Simbol & Keterangan \\
\hline Men-ben & Menulis bentuk || dan || \\
\hline Mem-per & Membentuk persamaan || | \\
\hline Menj-btk & Menjabarkan bentuk | dan | | sesuai definisi nilai mutlak \\
\hline a & ||$\{\mid$ \\
\hline b & ||$\{\mid$ \\
\hline Menj-pers & Menjabarkan persamaan | | | | menjadi empat kasus \\
\hline c & Menyelesaikan persamaan \\
\hline d & Menyelesaikan persamaan \\
\hline e & Menyelesaikan persamaan \\
\hline f & Menyelesaikan persamaan \\
\hline Kes & $\begin{array}{c}\text { Menarik kesimpulan berupa } \\
\{\quad\}\end{array}$ \\
\hline s & Selesai \\
\hline
\end{tabular}


Gambar 3 Diagram Proses Berpikir S1 dalam Menyelesaikan Soal nomor 2

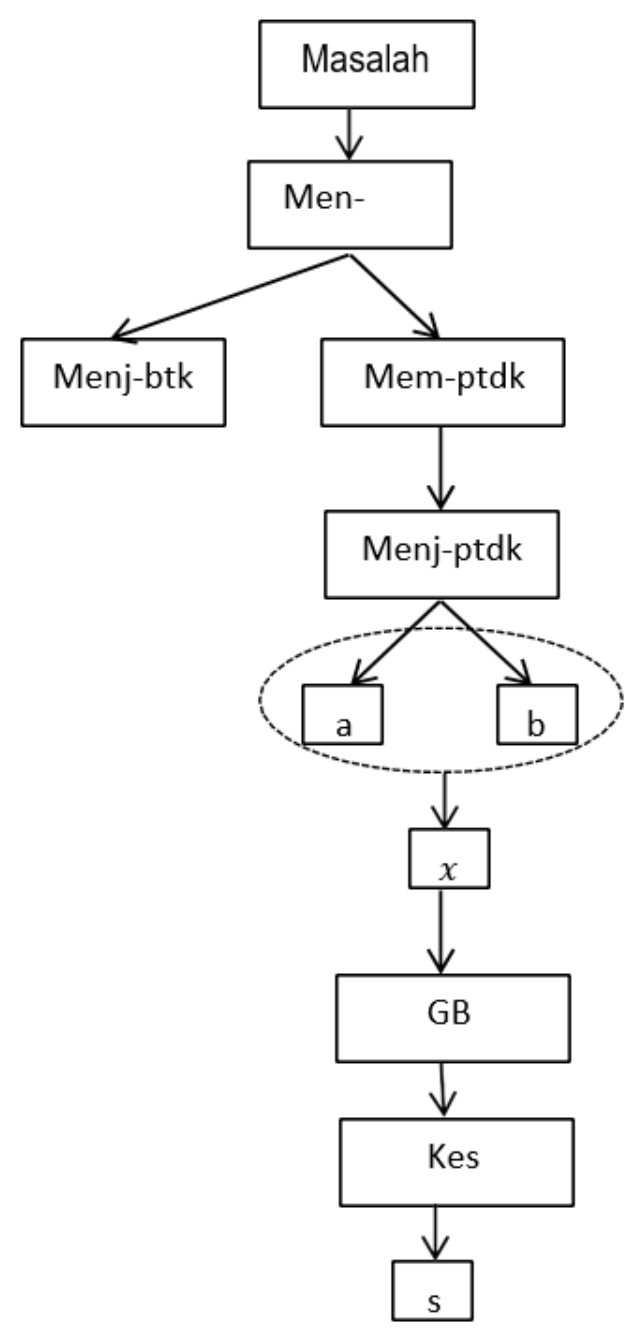

Tabel 2 Keterangan Diagram Proses berpikir S1

\begin{tabular}{|l|l|}
\hline Simbol & Keterangan \\
\hline Men-ben & Menulis bentuk I I \\
\hline Mem- ptdk & Membentuk pertidaksamaan I I \\
\hline Menj-btk & Menjabarkan bentuk Imenjadi dan \\
\hline Menj-ptdk & Menjabarkan pertidaksamaan I I menjadi dua kasus \\
\hline a & Menyelesaikan pertidaksamaan \\
\hline b & Menyelesaikan pertidaksamaan \\
\hline & Memperoleh nilai \\
\hline GB & Menggambar garis bilangan \\
\hline Kes & Menarik kesimpulan berupa $\{\mathbf{~}$ \\
\hline s & Selesai \\
\hline
\end{tabular}


Gambar 4 Diagram Proses Berpikir S2 dalamMenyelesaikan Soal Nomor 2

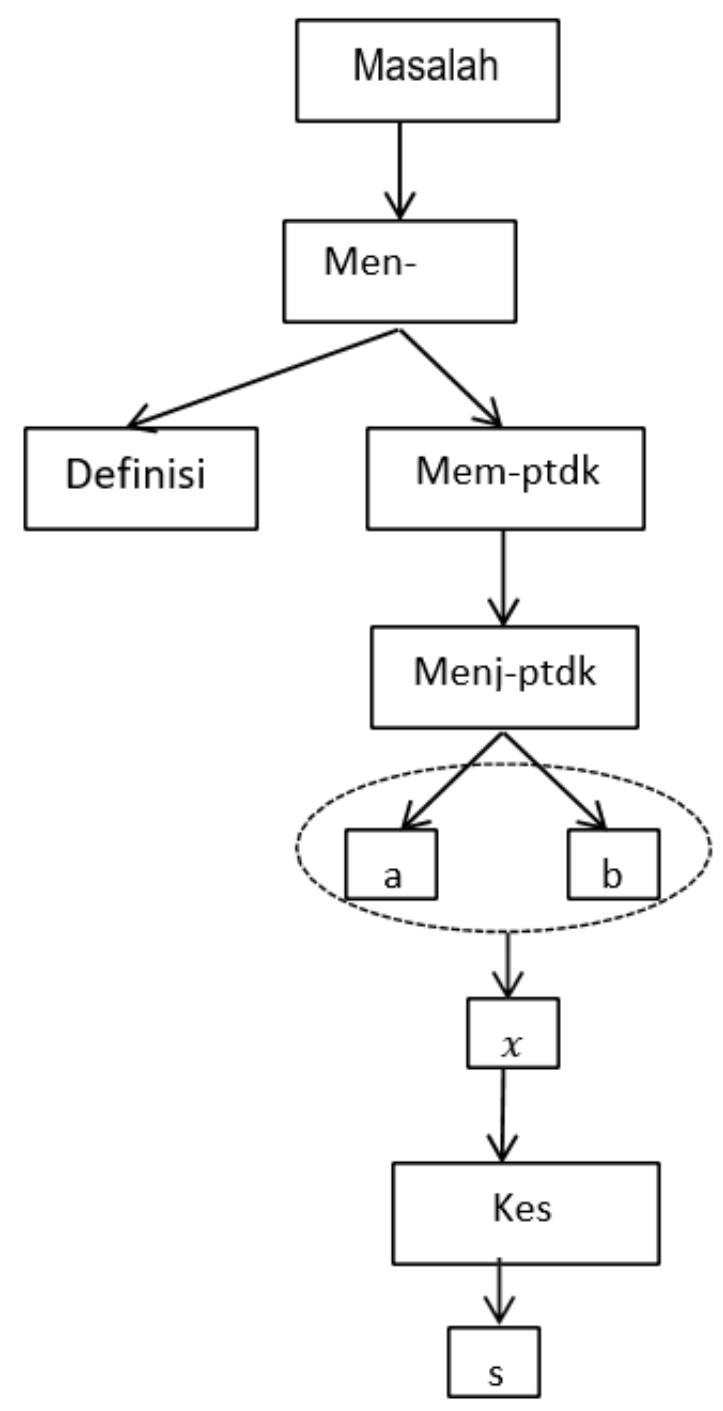

Tabel 3 Keterangan Diagram Proses berpikir S2

\begin{tabular}{|l|l|}
\hline Simbol & Keterangan \\
\hline Men-ben & Menulis bentuk | | \\
\hline Definisi & Mendefinisikan bentuk | | menjadi dan \\
\hline Mem-ptdk & Membentuk pertidaksamaan | | \\
\hline Mem-ptdk & Menjabarkan pertidaksamaan | I menjadi dua kasus \\
\hline a & Menyelesaikan pertidaksamaan \\
\hline b & Menyelesaikan pertidaksamaan \\
\hline & Memperoleh nilai \\
\hline Kes & Menarik kesimpulan berupa \{ $\}$ \\
\hline s & Selesai \\
\hline
\end{tabular}


Gambar 5 Diagram Proses Berpikir S3 dalamMenyelesaikan Soal Nomor 1

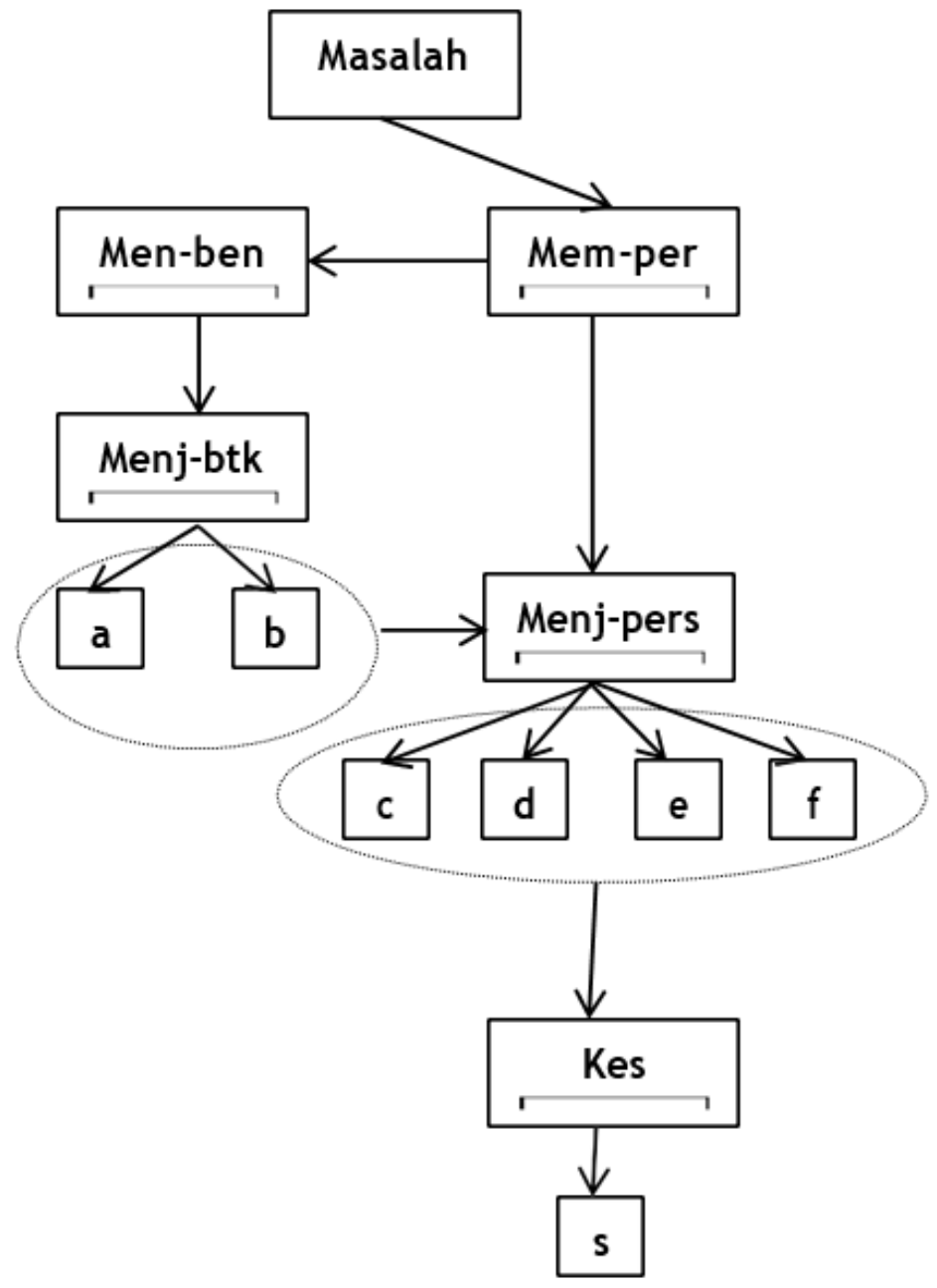

Tabel 4 Keterangan Diagram Proses berpikir S3

\begin{tabular}{|l|l|}
\hline Simbol & Keterangan \\
\hline Men-ben & Menulis bentuk || dan $\mid$ \\
\hline Mem-per & Menulis bentuk $\mid$ dan $\mid$ \\
\hline Menj-btk & Menulis bentuk || dan $\mid$ \\
\hline a & ||\{ \\
\hline b & ||\{ \\
\hline Menj-pers & Menjabarkan persamaan | | | menjadi empat kasus \\
\hline c & Menyelesaikan persamaan \\
\hline d & Menyelesaikan persamaan \\
\hline e & Menyelesaikan persamaan \\
\hline f & Menyelesaikan persamaan \\
\hline Kes & Selesai \\
\hline S &
\end{tabular}




\section{Simpulan}

\subsection{Simpulan}

Berdasarkan pembahasan yang telah dipaparkan, maka dapat disimpulkan bahwa proses berpikir siswa dalam menyelesaikan masalah nilai mutlak berdasarkan Teori Swartz adalah sebagai berikut. Pada tahap menghasilkan ide, siswa yang menjawab seluruh masalah yang diberikan secara benar, membentuk ide dengan menuliskan persamaan dan pertidaksamaan nilai mutlak secara lengkap. Siswa yang menjawab sebagian masalah dengan benar, menghasilkan ide dengan menulis persamaan secara lengkap namun pertidaksamaan tidak lengkap. Sedangkan siswa lain yang menjawab benar sebagian, melakukan hal sebaliknya yaitu menulis pertidaksamaan secara lengkap namun persamaan tidak lengkap. Pada tahap menjelaskan ide-ide, siswa menyusun dan mengembangkan langkah-langkah penyelesaian masalah dari ide awal yang telah dibentuk. Langkah-langkah penyelesaian masalah yang dilakukan siswa adalah dengan menjabarkan bentuk nilai mutlak sesuai definisi nilai mutlak kemudian dilanjutkan dengan mencari selesaian dari persamaan maupun pertidaksamaan nilai mutlak yang telah dibentuk. Selain itu, pada tahap ini siswa juga menjelaskan masing-masing tahapan yang dilakukan dalam menyelesaikan masalah. Proses yang dilakukan siswa dalam menilai kelayakan ide adalah dengan menelaah apakah ide yang dibentuk sudah mampu menjawab masalah atau tidak, kemudian siswa juga menguraikan hal-hal yang dijadikan dasar dalam membentuk ide penyelesaian masalah. Selain itu siswa juga mempertimbangkan apakah idenya layak atau tidak, yakni dengan cara menelaah apakah ide yang telah dihasilkan mampu menjawab masalah atau tidak. Pada tahap berpikir kompleks, siswa menuliskan kesimpulan yang dilakukan dengan cara menentukan himpunan penyelesaian dari persamaan dan pertidaksamaan nilai mutlak yang telah dibentuk.

\subsection{Saran}

Dari penelitian yang telah dilakukan, peneliti dapat memberikan saran sebagai berikut: Sesuai dengan tahapan proses berpikir berdasarkan Teori Swartz, (1) pada tahap menghasilkan ide, guru disarankan untuk menekankan agar siswa memahami

masalah dan mengaitkan dengan pengetahuan yang dimiliki untuk membentuk persamaan atau pertidaksamaan nilai mutlak, (2) pada tahap menjelaskan ide, guru lebih menekankan pada cara mendefinisikan nilai mutlak dan menentukan selesaian dari persamaan atau pertidaksamaan yang ada, (3) pada tahap menilai kelayakan ide, sebaiknya guru lebih menekankan pada cara menilai apakah jawaban yang dihasilkan mampu menjawab masalah atau tidak, dan (4) pada tahap berpikir kompleks menekankan pada caracara menarik kesimpulan dengan mempertimbangkan masing- masing jawaban yang ada.

\section{Daftar Rujukan}

Akinmola, E. A. (2014). Developing Mathematical Problem Solving Ability: a Panacea for a Sustainable Development in the 21 St Century. International Journal of Education and Research, 2(2), 1-8.

Jesica, A. (2016). Proses berpikir matematis mahasiswa dalam mengonstruksi bukti dengan induksi matematika berdasarkan teori berpikir Swartz (Doctoral dissertation, Universitas Negeri Malang). 


\section{Jurnal MIPA dan Pembelajarannya, 1(11), 2021, 844-854}

Kirk, PJ \& Ward, M.E. (1999). Understanding North Carolina Test: Thinking Skill Level (Volume 6). North Carolina: North Carolina Department of Public Instruction.

NCTM. (2000). Executive Summary: Principles and Standars of School Mathematics. United States of America: The National Council of Teachers of Mathematcs, Inc.

Supriadi, D., Mardiyana, M., \& Subanti, S. (2015). Analisis Proses Berpikir Siswa dalam Memecahkan Masalah Matematika Berdasarkan Langkah Polya Ditinjau Dari Kecerdasan Emosional Siswa Kelas VIII SMP Al Azhar Syifa Budi Tahun Pelajaran 2013/2014. Jurnal Pembelajaran Matematika, 3(2).

Swartz, R. J., Fischer, S. D., \& Parks, S. (1998). Infusing the Teaching of Critical and Creative Thinking into Secondary Science: A Lesson Design Handbook. Critical Thinking Books and Software, PO Box 448, Pacific Grove, CA 93950-0448. 